\title{
Assessment of Seed Vigor Tests for Crambe abyssinica
}

\author{
Tássia Fernanda Santos Neri Soares ${ }^{1}$, Bruno Antônio Lemos de Freitas ${ }^{1}$, José Geraldo de Araújo Ferreira Filho ${ }^{1}$, \\ Denise Cunha Fernandes dos Santos Dias ${ }^{1}$, Camila Andrade Fialho ${ }^{1}$, André Dantas de Medeiros ${ }^{1}$, \\ Rafael Macedo de Oliveira ${ }^{1} \&$ Alice de Souza Silveira ${ }^{1}$ \\ ${ }^{1}$ Departmento de Fitotecnia, Universidade Federal de Viçosa, Viçosa, Minas Gerais, Brazil \\ Correspondence: Tássia Fernanda Santos Neri Soares, Departmento de Fitotecnia, Universidade Federal de \\ Viçosa, Viçosa, Minas Gerais, Brazil. Tel: 55-31-3899-2619. E-mail: tassia.soares@ufv.br
}

Received: August 13, 2018

doi:10.5539/jas.v10n12p527
Accepted: September 19, $2018 \quad$ Online Published: November 15, 2018

URL: https://doi.org/10.5539/jas.v10n12p527

\begin{abstract}
Vigor tests are important mainly to identify differences associated to lots performance in field conditions. The objective of this study was to define the most appropriate tests to evaluate the crambe (Crambe abyssinica) seeds vigor. Seven seed lots of crambe were subjected to the standard germination (on the first and last count), germination speed index (GSI), primary root protrusion speed index (PRPSI), seedling length dry and weight seedling, water stress test using PEG 6000 at $-0.2 \mathrm{MPa}$, electrical conductivity and cold test without soil. Crambe lots studied had germination percentages varying from 54 to $80.5 \%$. The GSI, on the first count of water stress and electrical conductivity test ranked lots between two vigor classes The PRPSI, seedling length, seedling dry weight and last count of water stress tests were less sensitive to evaluate vigor for crambe seed. The cold test without soil and the first count of standard germination test were capable to dishtinguish lots more efficiently than the standard germination test on last count by ranking four of the seven seed lots studied.
\end{abstract}

Keywords: Brassicaceae, germination, physiological potential

\section{Introduction}

Alternative energy sources have been searched due to oil shortage in the last decades, highlighting oleaginous crops that in the past had only food purposes. In nowadays, biofuels production using vegetable oils is a global reality. Therefore, efforts are necessary to seek non-food crops, so that energy production does not affect food production (Lara-Fioreze et al., 2013). Many oilseeds species such as soybean, sunflower, peanut, babassu and turnip have been tested for biodiesel production. Among them stood out crambe (Crambe abyssinica) that belongs to Brassicaceae family, originates from Mediterranean Sea and widely planted in Mexico and United States. In the past, crambe production was basically destinded for hay due to its 30 to $32 \%$ of crude protein and in nowadays much of its cultivated area is destined for vegetable oil extraction (Costa et al., 2012; Werner et al., 2013).

Crambe is considered a cold-tolerant crop with potential for biodiesel industrial production due to its high lubricating potential and oil content in its composition, corresponding 30 and $45 \%$ in seeds (Toebe et al., 2010). In addition, crambe has the advantage of being able to be cultivated in the off-season. This fact is an excellent alternative for biodiesel production, considering that the oils used for this purpose are focused on annual crops, mainly during spring and summer cycle. Thereby, there is a lack of alternatives for autumn and winter cycle that allows to maintain industrial production in this period (Colodetti et al., 2012). There is only one genotype recorded for Brazilian conditions which is called "FMS Brilhante". It has genetic variability in several traits that allows gains in selection of higher oleaginous crops to reach energy production objective (Lara-Fioreze et al., 2013).

The use of high quality seeds has a great importance to ensure a successful stand establishment. Seed vigor affects not only the stand establishment, but also has influences in plant growth, development and productivity (Souza et al., 2009). Thus, vigor tests evaluate seed behavior under adverse conditions and reflect more accurately field emergence potential, unlike germination test that provides light, temperature and humidity optimum conditions. According to Alves et al. (2016), only germination test often is not enough to detect physiological potential differences in seeds. Then, vigor tests become an important tool for seed laboratory analysis. 
There are varieties of vigor tests that allow identifying physiological potential differences in seed lots that have a similar germination rate. Among the main vigor tests applied in seed analysis, are those that evaluate seed capacity to become seedlings faster by evaluation of the first count of germination test; membrane system speed reorganization by measuring electrical conductivity; tolerance to many seed stresses, such as drought and low temperatures. However, it is necessary to define which vigor tests promote a better lots differentiation for crambe seeds. Therefore, this study aims to define the most appropriate methods to evaluate crambe seeds physiological performanced by using vigor tests.

\section{Materials and Methods}

The experiment was conducted at Seed Analysis Laboratory localized in Universidade Federal de Viçosa (Minas Gerais, Brazil), during 2017 and 2018. Crambe (Crambe abyssinica) seeds that belongs to Cultivar FMS Brilliant cultivated by Mato Grosso do Sul Foundation. Seeds from different physiological ages were used to obtain the seven reference seed lots. A $3 \mathrm{~mm}$ sieve was used to standard seed size. The following vigor tests were perfomed in order to distinguish those lots in different vigor classes.

Standard Germination Test: conducted by using four replicates (each containing 50 seeds) for each lot. Seeds were sown in filter papers moistened with distilled water equivalent to 2.5 times of dry paper weight and placed in plastic boxes. Seeds were kept in a Biological Oxygen Demand incubator (B.O.D.) type germination chamber at $25{ }^{\circ} \mathrm{C}$ (MAPA, 2009). Normal seedling number was counted on fourth (first count) and seventh day (final count) after sowing, according to criteria established by Rules for Seed Analysis (MAPA, 2009). No treatments were used to break dormancy due to storage time that seeds were submitted.

Germination Speed Index (GSI): performed along with standard germination test by daily counting of normal seedlings number. It was calculated by sum of normal seedlings each day, divided by number of days after sowing, according to Maguire (1962):

$$
\mathrm{GSI}=\mathrm{G}_{1} / \mathrm{N}_{1}+\mathrm{G}_{2} / \mathrm{N}_{2}+\ldots+\mathrm{G}_{\mathrm{i}} / \mathrm{N}_{\mathrm{i}}
$$

Where,

$\mathrm{G}_{1}, \mathrm{G}_{2}, \mathrm{G}_{\mathrm{n}}=$ Normal seedling number observed in first, second and last day after sowing; $\mathrm{N}_{1}, \mathrm{~N}_{2}, \mathrm{~N}_{\mathrm{n}}=$ First, second and last day after sowing.

Primary Root Protrusion Speed Index (PRPSI): performed along with standard germination test by daily counting of seeds number that showed protrusion of primary root. It was calculated by sum of seeds number that showed protrusion of primary root each day, divided by number of days after sowing, according to Maguire (1962):

$$
\text { PRPSI }=\mathrm{P}_{1} / \mathrm{N}_{1}+\mathrm{P}_{2} / \mathrm{N}_{2}+\ldots+\mathrm{P}_{\mathrm{i}} / \mathrm{N}_{\mathrm{i}}
$$

Where,

$\mathrm{P}_{1}, \mathrm{P}_{2}, \mathrm{P}_{\mathrm{n}}=$ Seeds number that showed protrusion of primary root observed in first, second and last day after sowing; $\mathrm{N}_{1}, \mathrm{~N}_{2}, \mathrm{~N}_{\mathrm{n}}=$ First, second and last day after sowing.

Seedling Length (SL): carried out as a standard germination test, using four replicates (each containing 25 seeds) for each lot. After seven days of sowing, 10 normal seedlings were randomly removed and measured using a rule. Results were expressed in $\mathrm{mm} / \mathrm{seedling}$.

Seedling Dry Weight (SDW): carried out as a standard germination test, using four replicates (each containing 25 seeds) for each lot. After seven days of sowing, 10 normal seedlings were randomly removed, arranged in Kraft paper bags and placed into forced air oven at $65{ }^{\circ} \mathrm{C}$ (Machado et al., 2016), until reaching constant weight. Results were expressed in $\mathrm{mm} /$ seedling.

Water Stress Test: conducted using using four replicates (each containing 25 seeds) for each lot. Seeds were sown in filter papers moistened with PEG 6000 solution at $-0.2 \mathrm{MPa}$ equivalent to 2.5 times of dry paper weight and placed into plastic boxes. Seeds were kept in a B.O.D. type germination chamber at $25^{\circ} \mathrm{C}$. Number of normal seedling was counted on fourth (first count) and seventh day (final count) after sowing, according to criteria established by Rules for Seed Analysis (MAPA, 2009).

Cold Test Without Soil: conducted using four replicates (each containing 25 seeds) for each lot. Seeds were sown in filter papers moistened with distilled water equivalent to 3 times of dry paper weight and placed in plastic boxes. Prior to assembling test, filter papers moistened were maintained at $10{ }^{\circ} \mathrm{C}$ for 24 hours. Seeds were kept in a B.O.D type germination chamber at $10^{\circ} \mathrm{C}$ for seven days. After that, they were transferred to another B.O.D 
type germination chamber at $25{ }^{\circ} \mathrm{C}$ for five days. Then, number of normal seedlings were recorded and germination percentage was calculated.

Electrical conductivity: performed using four replicates (each containing 100 seeds) for each lot. Seeds were weighed and placed in plastic cups containing $50 \mathrm{~mL}$ of distilled water for 24 hours and kept in a B.O.D. type germination chamber at $25{ }^{\circ} \mathrm{C}$. After that, electrical conductivity of soaking solution was measured using a digital conductivity meter (Digimed DM-32). Results were expressed in $\mu \mathrm{S} \mathrm{cm}^{-1} \mathrm{~g}^{-1}$.

Data statistical analysis: completely randomly design was set up, using four replicates per each lot. The data were submitted to analysis of variance, preceded by the normality test and variance homoscedasticity, using software R 3.2.2 (R Development Core Team, 2015). The mean values were compared by Tukey test at 5\% probability.

\section{Results and Discussion}

According to the standard germination test on the seventh day, seed germination varies from 54 to $80.5 \%$. Lots 1 to 4 showed higher germination percentages compared to lots 5 to 7 , although no significant differences were observed among lot 6 and the others (Table 1). In order to adquire more conclusive information about the physiological potential of these lots, the application of vigor tests is justified since the objective is to simulate adverses condtions, in which seeds may be submitted in the field. On the other hand, the germination test is performed under optimum conditions with controlled factors, such as temperature, light and humidity, and may not represent field conditions.

Table 1. Standard germination (\%) recorded on fourth (first count) and seventh day (final count) after sowing for the seven crambe seed lots

\begin{tabular}{lll}
\hline \multirow{2}{*}{ Lots } & \multicolumn{2}{c}{ Standard Germination $(\%)$} \\
\cline { 2 - 3 } & First count & Final count \\
\hline 1 & $65.0 \mathrm{ab}^{*}$ & $80.5 \mathrm{a}$ \\
2 & $48.5 \mathrm{bcd}$ & $79.0 \mathrm{a}$ \\
3 & $67.5 \mathrm{a}$ & $77.0 \mathrm{a}$ \\
4 & $55.0 \mathrm{abc}$ & $77.0 \mathrm{a}$ \\
5 & $73.5 \mathrm{a}$ & $66.5 \mathrm{ab}$ \\
6 & $38.5 \mathrm{~cd}$ & $58.0 \mathrm{~b}$ \\
7 & $33.0 \mathrm{~d}$ & $54.0 \mathrm{~b}$ \\
\hline $\mathrm{CV}(\%)$ & 15.09 & 11.01 \\
\hline
\end{tabular}

Note. ${ }^{*}$ Means followed by the same letter in the column do not differ by Tukey test at $5 \%$ probability.

On the first count of standard germination test (the fourth day), lots 3 and 5 stood out for being more vigorous, but statistically similar to lots 1 and 4 . Lot 6 and 2 had no statistical differences compared to lot 7 that showed a lower vigor. The first count of standard germination test is considered one of the vigor tests that can be performed along with the standard germination test, but taking a less time-consuming (Martins et al., 2002). In some cases, a first count of the standard germination test express better differences in germination speed (Bento et al., 2010). So that, seeds have a higher germination values in a first count could be considered more vigorous (Barros et al., 2002).

Evaluating the standard germination test on the fourth day promoted a better lots differentiation compared to its counting on the seventh day. This fact suggests that it is not necessary to prolong this test utill the last count, which can be more practical in commercial seed laboratory analyzes. In order words, the first count may be considered simplified method for being more feasible (Havstad et al., 2011).

An important point to emphasize is that crambe seeds have a tegumentary structure, called pericarp. Its main function is to protect seeds during storage by reducing germination potential loss. However, in some cases, pericarp can lead to germination unevenness or even germination absence (Amaro et al., 2014). Along with this, majority of fungi that causes sanitary issues happens on pericarp of crambe seeds. Studies show that Alternaria brassicicola is one of main pathogens responsible for seed darkness and germination potential loss (Moers et al., 2012). 
Using the Germination Speed Index (Table 2) was possible to distinguish lots into two vigor classes, high (lots 2 and 4) and low (lots 5,6 and 7) vigor. However, lots 1 and 3 didn't differ statistically from the others. The main goal of vigor tests is to identify possible differences in the physiological potential of seed lots that have similar germination percentages. The Germination Speed Index, a parameter that correspond to the velocity in which seed germinates, may be considered more sensible for detecting small differences in seeds physiological quality compared to a standard germination test (Marcos Filho, 2015).

Table 2. Germination Speed Index (GSI) and Primary Root Protrusion Speed Index (PRPSI) recorded daily for the seven crambe seed lots. Seedling length $(\mathrm{mm})$ and seedling dry weight $(\mathrm{mg})$ determined on seventh day after sowing for the seven crambe seed lots

\begin{tabular}{lllll}
\hline Lots & GSI & PRPSI & Seedling length $(\mathrm{mm})$ & Seedling dry weight $(\mathrm{mg})$ \\
\hline 1 & $8.19 \mathrm{ab}$ & $18.57 \mathrm{a}$ & $62.87 \mathrm{a}$ & $4.77 \mathrm{a}$ \\
2 & $10.17 \mathrm{a}$ & $18.18 \mathrm{a}$ & $76.90 \mathrm{a}$ & $4.75 \mathrm{a}$ \\
3 & $8.47 \mathrm{ab}$ & $16.33 \mathrm{a}$ & $63.00 \mathrm{a}$ & $4.31 \mathrm{a}$ \\
4 & $10.09 \mathrm{a}$ & $17.40 \mathrm{a}$ & $67.42 \mathrm{a}$ & $4.56 \mathrm{a}$ \\
5 & $7.17 \mathrm{~b}$ & $17.03 \mathrm{a}$ & $68.60 \mathrm{a}$ & $4.80 \mathrm{a}$ \\
6 & $7.35 \mathrm{~b}$ & $18.19 \mathrm{a}$ & $70.30 \mathrm{a}$ & $4.92 \mathrm{a}$ \\
7 & $6.86 \mathrm{~b}$ & $16.73 \mathrm{a}$ & $63.02 \mathrm{a}$ & $5.32 \mathrm{a}$ \\
\hline CV $(\%)$ & 12.67 & 11.65 & 10.83 & 8.59
\end{tabular}

Note. * Means followed by the same letter in the column do not differ by Tukey test at 5\% probability.

The PRPSI was not efficient to provide lots differentiation for crambe seeds. In fact, it is not necessary to execute GSI and PRPSI together, so only GSI could be used for differing crambe seed lots. The PRPSI associates quantity of seeds that emits primary root and its speed. Despite it doesn't evaluate seedling according to seed technology criteria, PRPSI may be used as a parameter to end germination test before its last count (Toledo et al., 2011).

In this study, seedling length and seedling dry weight variables did not provide lots differentiation. However, this non-differentitation of lots does not imply that theses tests are inappropriate for evaluation of crambe seed vigor. Since the vigor influence occurs in all germinative aspects, from germination speed to the dry matter allocation in the seedlings (Gehling et al., 2017). Santos and Rossetto (2013) found similar results using those same parameters for crambe seed lots differentiation of FMS Brilhante cultivar. In contrast, Leão-araújo et al. (2017)

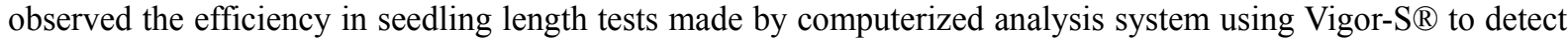
differences in physiological quality of crambe seed lots.

Regarding the cold test, all lots showed a decrease in germination compared to the results of the standard germination test. These results corroborate those found by Cruz-Silva et al. (2015) using the cold test to evaluate crambe seeds germination. The cold test provided satisfactory results for classifying crambe seeds in four of seven studied lots (Table 3). Lot 1 had a higher vigor, but was equal statistically to others lots (3, 5 and 6). Lot 4 had the worst performance, belonging to the lowest vigor class, so that, it could not be recommended for using in cold and humid areas.

According to Marcos Filho (2015), the cold test can be considered as the oldest vigor test and the most popular test applied to evaluate seed vigor in the United States. This test aims to evaluate seed responses submitted to low temperature and high humidity degree conditions. Thus, temperature below to optimum germination provokes cell solutes leakage due to membrane systems disorganization. 
Table 3. The electrical conductivity, cold test water stress test germination (\%) recorded on fourth (first count) and seventh day (final count) after sowing for the seven crambe seed lots

\begin{tabular}{|c|c|c|c|c|}
\hline \multirow{2}{*}{ Lots } & \multirow{2}{*}{$\begin{array}{l}\text { Electrical Conductivity } \\
\left(\mu \mathrm{S} \mathrm{cm}^{-1} \mathrm{~g}^{-1}\right)\end{array}$} & \multirow{2}{*}{$\begin{array}{l}\text { Cold Test } \\
(\% \text { germination })\end{array}$} & \multicolumn{2}{|c|}{ Water Stress ( $\%$ germination) } \\
\hline & & & First count & Final count \\
\hline 1 & $566.23 \mathrm{~b}$ & $74.0 \mathrm{a}$ & $45.0 \mathrm{ab}$ & $74.0 \mathrm{a}$ \\
\hline 2 & $605.13 \mathrm{~b}$ & $34.5 \mathrm{~cd}$ & $39.0 \mathrm{ab}$ & $75.5 \mathrm{a}$ \\
\hline 3 & $436.53 \mathrm{a}$ & $68.0 \mathrm{ab}$ & $55.5 \mathrm{a}$ & $81.0 \mathrm{a}$ \\
\hline 4 & $582.86 \mathrm{~b}$ & $13.0 \mathrm{~d}$ & $29.5 \mathrm{~b}$ & $70.0 \mathrm{a}$ \\
\hline 5 & $463.42 \mathrm{a}$ & $59.5 \mathrm{ab}$ & $47.5 \mathrm{ab}$ & $70.0 \mathrm{a}$ \\
\hline 6 & $422.26 \mathrm{a}$ & $53.5 \mathrm{abc}$ & $50.5 \mathrm{a}$ & $80.0 \mathrm{a}$ \\
\hline 7 & $450.41 \mathrm{a}$ & $49 \mathrm{bc}$ & $51.5 \mathrm{a}$ & $75.0 \mathrm{a}$ \\
\hline $\mathrm{CV}(\%)$ & 4.93 & 20.46 & 17.94 & 9.39 \\
\hline
\end{tabular}

Note. * Means followed by the same letter in the column do not differ by Tukey test at 5\% probability.

The electrical conductivity test divided the seven lots studied into two vigor classes: high vigor (lots 3, 5, 6 and 7) and low vigor (lots1, 2 and 4). Avila et al. (2005) found similar results by ranking two of four studied lots in brassica napus seeds. Cruz et al. (2013) reported that high values of electrical conductivity in crambe seeds may probably be explained by the presence of pericarp. This seed hull may contribute to cell membranes permeability for increasing the amount of leaching, especcially due to structures lignified and ions carriers. The main principle of electrical conductivity test is based on embedded seeds deterioration, in which occurs membrane systems integrity loss and cellular components leaching. Thus, a high conductivity value is characterized by a higher solutes leaching from seeds being a less vigorous seeds behavior (Vieira \& Krzyzanowski, 1999).

The water stress test on the first count discriminated two of seven studied lots, in which lot 3, 6 and 7 are the most vigorous. Lot 4 had only $29.5 \%$ of normal seedling and was considered the least vigoros, befitting the results of the cold test. Machado et al. (2017) and Texeira et al. (2011) reported that PEG soultions with osmotic potentials equal ou lower than -0.2 MPa negatively affect crambe seeds physiological quality. On the last count of water stress test, it was not possible discriminate lots into vigor classes. Thus, keeping seed on water restriction using PEG 6000 until last count is not recommended in order to classify crambe seed into different lots.

According to Martins et al. (2002), the first count of germination test is a simple, practical and economical way to evaluate germination speed that during seed deterioration is one of the first parameter to be affected. Water restriction in seeds is responsible for delaying on germination, which is not desirable under field conditions. Thus, seed are exposed for a longer time to adverse conditions such as pathogens action and insects and pest's attacks (Machado et al., 2017).

As illustrated in Figure 1, it is possible to observe a higher root growth of crambe seed submitted to water stress test compared to standard germination test on seventh day after sowing (Figure 1). Yoshimura et al. (2008) described a drought prevent mechanism by increasing root growth, in which many induced proteins, during water restriction initial stage, are involved in root morphogenesis and carbon/nitrogen metabolism. 

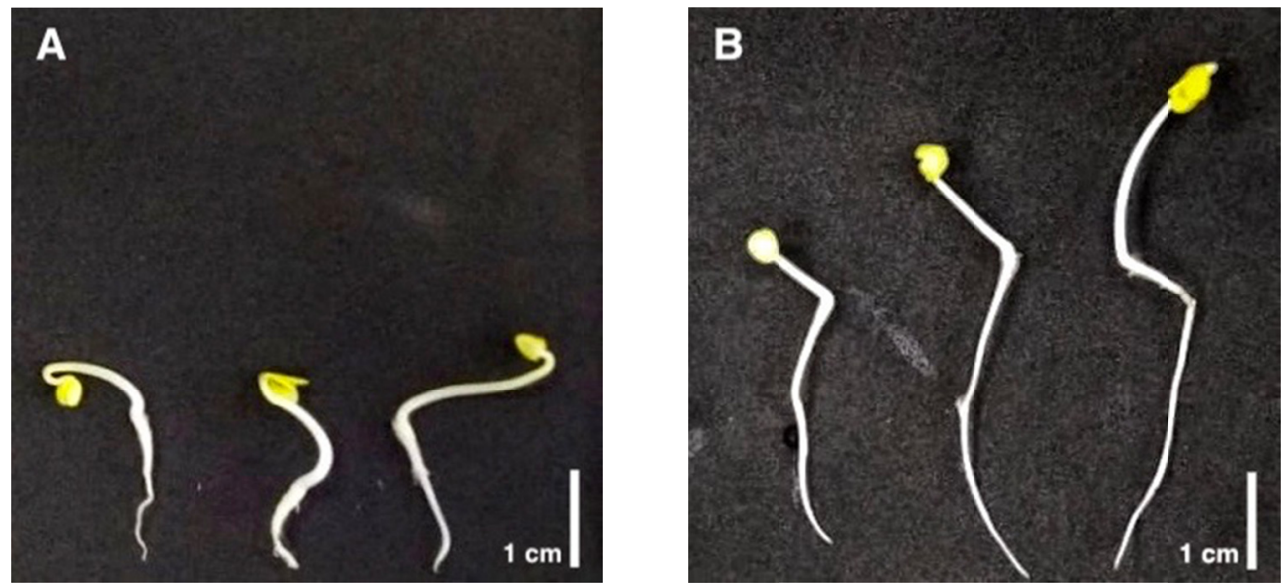

Figure 1. Normal seedlings of standard germination test on seventh day after sowing (A). Normal seedlings of water stress test on seventh day after sowing (B)

\section{Conclusion}

The cold test without soil and first count of standard germination test are considered the best vigor tests for differentiating crambe seed of FMS Brilhante cultivar into more vigor classes.

\section{Acknowledgements}

We thank CNPq, CAPES and FAPEMIG for the financial support.

\section{References}

Alves, C. Z., Rodrigues, L. A., Rego, C. H. Q., \& Silva, J. B. da. (2016). pH of exudate test in the physiological quality of crambe seeds. Ciência Rural, 46(6), 1014-1018. https://doi.org/10.1590/0103-8478cr20141838

Amaro, H. T. R., De Souza David, A. M. S., Neta, I. C. S., Oliveira Assis, M., Araújo, E. F., \& Araújo, R. F. (2014). Teste de envelhecimento acelerado em sementes de crambe (Crambe abyssinica Hochst), cultivar FMS Brilhante. Revista Ceres, 61(2), 202-208. https://doi.org/10.1590/S0034-737X2014000200007

Ávila, M. R., Braccini, A. D. L., Scapim, C. A., Martorelli, D. T., \& Albrecht, L. P. (2005). Testes de laboratório em sementes de canola e a correlação com a emergência das plântulas em campo. Revista Brasileira de Sementes, 27(1), 62-70. https://doi.org/10.1590/S0101-31222005000100008

Barros, D. I., Nunes, H. V., Dias, D., Cunha F. S., \& Bhering, M. C. (2002). Comparação entre testes de vigor para avaliação da qualidade fisiológica de sementes de tomate. Revista Brasileira de Sementes, 24(2), 12-16. https://doi.org/10.1590/S0101-31222002000100003

Bento, S. R. S. de O., Santos, A. E. O. dos, Melo, D. R. M. de, \& Torres, S. B. (2010). Eficiência dos testes de vigor na avaliação da qualidade fisiológica de sementes de mulungu (Erythrina velutina Willd.). Revista Brasileira de Sementes, 32(4), 111-117. https://doi.org/10.1590/S0101-31222010000400012

Colodetti, T. V., Martins, L. D., Rodrigues, W. N., Brinate, S. V. B., \& Tomaz, M. A. (2012). Crambe: aspectos gerais da produção agrícola. Revista Enciclopédia Biosfera, 8, 258-269.

Costa, L. M., Resende, O., Gonçalves, D. N., Souza, K. A., Sales, J. D. F., \& Donadon, J. R. (2012). The influence of drying on the physiological quality of crambe fruits. Acta Scientiarum. Agronomy, 34(2). https://doi.org/10.4025/actasciagron.v34i2.12482

Cruz, S. M., Nery, M. C., Rocha, A. D. S., Von Pinho, É. V. D. R., Andrade, P. C. D. R., \& Dias, D. C. F. D. S. (2013). Vigor tests for evaluation of crambe (Crambe abyssinica Hochst) seed quality. Journal of Seed Science, 35(4), 485-494. https://doi.org/10.1590/S2317-15372013000400010

Gehling, V. M., Mendonça, A. O. De, Cunha, F., Avila, G. D., Villela, F. A., \& Aumonde, T. Z. (2017). Desempenho fisiológico de sementes e plântulas de tomateiro sob diferentes temperaturas. Scientia Agraria Paranaensis, 16(1), 32-38. https://doi.org/10.18188/1983-1471/sap.v16n1p32-38

Havstad, T., Aamlid, T. S., \& Lomholt, A. (2011). Evaluation of vigour tests for determination of seed storage potential in red clover (Trifolium pratensis L.) and timothy (Phleum pratense L.). Seed Science and Technology, 39(3), 637-648. https://doi.org/10.15258/sst.2011.39.3.10 
Lara-Fioreze, A. C. C., Tomaz, C. A., Fioreze, S. L., Pilon, C., \& Zanotto, M. D. (2013). Genetic diversity among progenies of Crambe abyssinica Hochst for seed traits. Industrial Crops and Products, 50, 771-775. https://doi.org/10.1016/j.indcrop.2013.07.039

Leão-araújo, E. F., Faria, J., Barboza, C., Marcos-Filho, J., \& Vieira, R. D. (2017). Controlled deterioration test and use of the Seed Vigor Imaging System (SVIS ${ }^{\circledR}$ ) to evaluate the physiological potential of crambe seeds. Journal of Seed Science, 39(4), 393-400. https://doi.org/10.1590/2317-1545v39n4177911

Machado, F. H. B., David, A. M. S. de S., Cangussú, L. V. S., Figueiredo, J. C., \& Amaro, H. T. R. (2017). Physiological quality of seed and seedling performance of crambe genotypes under water stress. Revista Brasileira de Engenharia Agricola e Ambiental, 21(3), 175-179. https://doi.org/10.1590/1807-1929/ agriambi.v21n3p175-179

Maguire, J. D. (1962). Speed of germination-aid selection and evaluation for seedling emergence and vigor. Crop Science, 2, 176-177. https://doi.org/http://dx.doi.org/10.2135/cropsci1962.0011183X000200020033x

MAPA (Ministério da Agricultura, Pecuária e Abastecimento). (2009). Regras para análise de sementes. Brasília, DF: MAPA/ACS.

Marcos Filho, J. (2015). Seed vigor testing: an overview of the past, present and future perspective. Scientia Agricola, 72(4), 363-374. https://doi.org/10.1590/0103-9016-2015-0007

Martins, C. C., Martinelli-Seneme, A., Castro, M. M., Nakagawa, J., \& Cavariani, C. (2002). Comparação entre métodos para a avaliação do vigor de lotes de sementes de couve-brócolos (Brassica oleracea $\mathrm{L}$. var. Italica Plenk). Revista Brasileira de Sementes, 24, 96-101. https://doi.org/10.1590/S0101-31222002000200016

Moers, E. M., Kuhn, O. J., Gonçalves Jr, A. C., Franzener, G., \& Stangarlin, J. R. (2012). Levantamento de Doenças na cultura do crambe (Crambe abyssinica Hochst) na região oeste do Paraná. Scientia Agraria Paranaenis, 11(1), 35-48. https://doi.org/10.18188/1983-1471/sap.v11n1p35-48

R Development Core Team. (2015). R: A language and environment for statistical computing. Vienna, Austria: R Foundation for Statistical Computing. Retrieved from http://r-project.org

Santos, L. A. S. Dos, \& Rossetto, C. A. V. (2013). Testes de vigor em sementes de Crambe abyssinica. Ciência Rural, 43(2), 233-238. https://doi.org/10.1590/S0103-84782013000200007

Souza, S. A. de, Nakagawa, J., \& Machado, C. G. (2009). Teste de envelhecimento acelerado em sementes de aveia preta. Revista Brasileira de Sementes, 31(2), 155-163. https://doi.org/10.1590/S0101-3122200900 0200018

Teixeira, R. N., Toledo, M. Z., Ferreira, G., Cavariani, C., \& Jasper, S. P. (2018). Germinação e vigor de sementes de crambe sob estresse hídrico. Irriga, 16(1), 42. https://doi.org/10.15809/irriga.2011v16n1p42

Toebe, M., Lopes, S. J., Storck, L., Silveira, T. R. da, Milani, M., \& Casarotto, G. (2010). Estimativa de plastocrono em crambe. Ciência Rural, 40(4), 793-799. https://doi.org/10.1590/S0103-84782010005000054

Toledo, M. Z., Teixeira, R. N., Ferrari, T. B., Ferreira, G., Cavariani, C., \& Cataneo, A. C. (2011). Physiological quality and enzymatic activity of crambe seeds after the accelerated aging test. Acta Scientiarum. Agronomy, 33(4), 687-694. https://doi.org/10.4025/actasciagron.v33i4.8248

Vieira, R. D., \& Krzyzanowski, F. C. (1999). Teste de condutividade elétrica. In F. C. Krzyananowski, R. D. Vieira, \& J. de B. França-Neto (Eds.), Vigor de sementes: Conceitos e testes (pp. 1-26). Londrina, PR: Abrates.

Werner, E. T., Lopes, J. C., Gomes Junior, D., Luber, J., \& Amaral, J. A. T. do. (2013). Accelerated aging test to evaluate the quality of crambe (Crambe abyssinica Hochst-Brassicaceae) seed physiology. Idesia (Arica), 31(1), 35-43. https://doi.org/10.4067/S0718-34292013000100005

Yoshimura, K., Masuda, A., Kuwano, M., Yokota, A., \& Akashi, K. (2008). Programmed proteome response for drought avoidance/tolerance in the root of a $\mathrm{C} 3$ xerophyte (wild watermelon) under water deficits. Plant and Cell Physiology, 49(2), 226-241. https://doi.org/10.1093/pcp/pcm180

\section{Copyrights}

Copyright for this article is retained by the author(s), with first publication rights granted to the journal.

This is an open-access article distributed under the terms and conditions of the Creative Commons Attribution license (http://creativecommons.org/licenses/by/4.0/). 